\title{
El cielo como triunfo: \\ Los galardones de la palma y la corona en Gonzalo de Berceo ${ }^{1}$
}

\author{
ANTONIO CEA GUTIÉRREZ \\ Dpto. de Antropología. CSIC. Madrid
}

Al Santo de Cañas y Silos

en el milenario de su nacimiento.

\section{RESUMEN}

La reutilización de los símbolos clásicos de la corona y la palma como premios celestiales en la vita post mortem se estudia aquí a través de la obra del riojano Gonzalo de Berceo, que vivió a caballo entre los siglos XII y xIII. El análisis textual sobre los ceremoniales de coronación y de triunfo, así como de las fuentes, en gran parte evangélicas (canónicas y apócrifas), de las que bebe este autor, se completa con ejemplos de la iconografía precedente, coetánea y también la que se ha generado hasta hoy, quizá por la pervivencia religiosa de la tradición oral y escrita.

\section{SUMMARY}

The work of Gonzalo de Berceo, a native of the Rioja region of Spain who lived in the $12^{\text {th }}$ and $13^{\text {th }}$ centuries, illustrates the reutilization of the classic symbols of the crown and the palm as heavenly awards in the afterlife. The author analyzes Berceo's texts on the rituals of coronation and triumph as well as his sources, most of which were the canonical and the apocryphal Gospels. The author brings iconography to bear on this analysis: the iconography before and during Berceo's time as well as that which has been produced since, possibly because of the religious endurance of the oral and written tradition.

Palabras clave: Religiosidad. Palma. Corona. Premio celestial. Santidad. Iconografía. Fuentes literarias. Gonzalo de Beceo.

Key words: Religion. Palm. Crown. Heavenly award. Holiness. Iconography. Literary sources. Gonzalo de Berceo.

RDTP, LVI, 2 (2001): 5-32 
El pensamiento y las creencias medievales acerca del encumbramiento del alma en la gloria celestial y el disfrute de los imperecederos galardones, como la corona y la palma, se reflejan con fidelidad en la obra de Berceo y en la iconografía de su tiempo, donde los santos y, en grado supremo, la Virgen son espejo de virtud para el cristiano.

La corona y los demás atributos, símbolos de la autoridad y del poder real - vigentes a lo largo de la Historia y, de manera especial, en la Edad Media, donde se da una fusión del cristianismo con el mundo clásico- están muy patentes en las fuentes de las que Berceo bebe, y parecen seguir de cerca los regalia del Sacro Imperio, ante los que el Pueblo se postraba como ante el propio emperador. El trono era la insignia principal de majestad, además del cetro, la espada, el orbe o globo, los brazaletes, el manto y la corona, símbolos que legitimaban la investidura.

En ese Imperio, donde la transmisión de poder no se fundaba en el derecho de sucesión sino que era electiva, estos regalia adquirieron una importancia añadida. Por esa misma razón (y puesto que la idea religiosa se une a la política) eran ejemplo perfecto para el cristiano, que no tenía garantizado el triunfo de la gloria celestial y debía conquistarlo a diario, ejercitando la virtud hasta convertirse en homo-miles victoriosus.

Esta convicción daría lugar a la utilización hagiográfica de la corona en su variante dúplice: la corona real o imperial, de metales y piedras preciosos que hacen reina al alma después de la muerte, y la corona vegetal de laureles y flores que, junto con la palma - elementos del mundo clásico- simboliza la victoria militar en las batallas y la corporal en los juegos (en el alma es el triunfo por el martirio y las virtudes contra los vicios y el maligno).

En las apoteosis de coronación, terrenal o celestial, que nos describen las fuentes escritas y especialmente la pintura, este ritual puede tener lugar en un espacio teatral - de gradas, estrado y trono, como arquitecturas de quita y pon-, donde ángeles cantores e instrumenteros solemnizan el momento, y otros son portadores que presentan las insignias de la majestad, mientras santos y cortesanos contemplan la escena arrodillados.

Puede darse también la coronación en un ámbito de resurrección, con una estructura de nubes y rayos de luz, donde se asienta, mirona, la corte celestial, o en un lugar interespacial, a medio camino entre la muerte y la gloria, especialmente en la iconografía de la Dormición de la Virgen.

${ }^{1}$ El presente estudio es continuación del que se publicó en esta misma Revista - RDTP LIV, 1. ${ }^{\circ}$ (1999): 93-102- titulado: "Religiosidad y comunicación interespacial en la Edad Media. Los viajes celestiales en el Poema de Santa Oria. 
En tercer lugar, y al menos desde época tardomedieval, hasta casi finalizado el siglo $\mathrm{XIX}^{2}$, el lugar de la coronación podía ser también un tipo de paraíso terrenal, locus amoenus, Parnaso, floresta o "selvático theatro". La causa de coronación no era solo por estricta virtud (como en la tabla central del políptico de Gante), sino, sobre todo, por méritos poéticos, en una atmósfera cortesana, con corona de hojas de laurel y de roble, tal y como se describe en La coronación del marqués de Santillana (Juan de Mena 1989: 101).

E aquesta corona, de fojas e ramas de dos árboles: de laurel, porque denota alabança e gloria de sabiduría, de las quales fueron coronados Vergilio, Omero, Ovidio e otros; otrosí es coronado de ramas e corona de robles, que denota ferocidad e valentía e esperto conosçimiento de la militar diçiplina, de la qual corona fue coronado el grande Ércoles ${ }^{3}$.

En el momento culminante de la coronación - suele representarse como prototipo la de María-, se dan una combinación de variables en cuanto al protocolo y gestualidad de los celebrantes. En primer lugar, que la posición de quien otorga y quien recibe la corona esté lateralizada, María de rodillas y Cristo sentado en trono; ambos presentados de perfil o de tres cuartos. Que María ocupe el centro de la composición, si es coronada por la Trinidad y de cara al orante, no de espaldas, como estaría en realidad en la ceremonia. Por último, cuando Nuestra Señora aparece como trono de la Sabiduría, con el Niño en el regazo, en un espacio áulico o doméstico privado, al que acuden a coronarla dos ángeles. En las apoteosis reales los monarcas reciben la corona de la mano de Cristo, que se deja asomar entre nubes.

Dentro de estas distintas actitudes y coronas (real, imperial y corona triple o tiara) pueden manifestarse las variantes siguientes:

- coronados coronantes (generalmente Cristo o el Padre Eterno a la Virgen);

- no coronados coronando (el Espíritu Santo, o los ángeles con relación a María);

\footnotetext{
${ }^{2}$ En el célebre cuadro de la coronación como poeta de M. J. Quintana por la reina Isabel II, obra de Luis López Piquer (1859), hay en realidad una contaminación de atributos, al celebrarse la ceremonia en el salón del Senado mezclándose de este modo la corona real con la de laurel. También un reconocimiento público de quien se ciñe una corona heredada hacia el que la adquiere por méritos.

${ }^{3}$ Sobre el pasaje relativo a la coronación de Mossen Jordi, ver Marqués de Santillana (1989: I, 156-159).
} 
- coronantes coronando (santos que están recibiendo este galardón al tiempo que lo otorgan; rareza que tan primorosamente pinta Simone Martini en la tabla del obispo San Luis de Tolosa, coronado por dos querubines y coronando a Roberto de Anjeo [Nápoles, Museo de Capodimonte]) (Tarabon 1973).

El poder de estos dos símbolos: la corona, materializada sacralización de la autoridad - que antes dimanaba de la gracia divina y ahora del

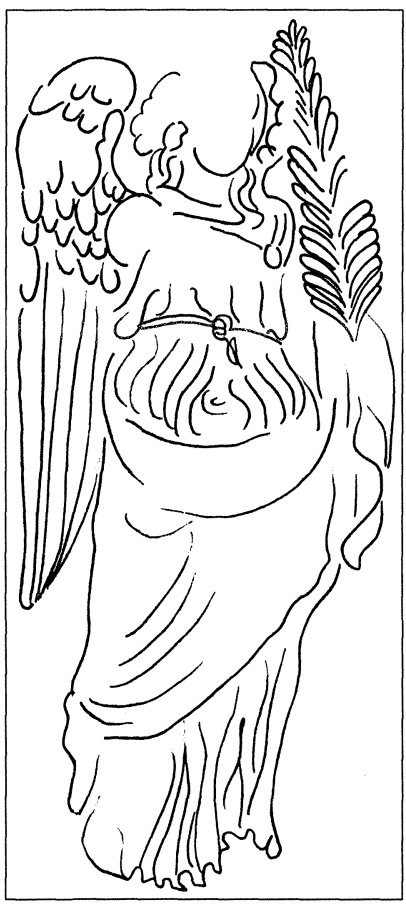

Pueblo-, y la rama de palma, emblema de la victoria por competición -en el mundo cristiano, sometiendo el cuerpo a la virtud y hoy encumbrándolo por el juego y el atletismo-, siguen tan vigentes como en el mundo clásico.

\section{EL GALARDÓN DE LA PALMA}

Cabría esperar que la palma -emblema generalizado de la victoria y, en la simbología cristiana ${ }^{4}$, especialmente de la castidad y el martirio- estuviera bien representada en la producción de Berceo, al menos en las vitae y, desde luego, en la Pasión de San Lorenzo,

Figura 1.-La palma como triunfo de la virtud entre los santos es deudora del panteón clásico. Victoria del arco de Constantino (Roma, s. IV). Dibujo de A. Cea.

${ }^{4}$ El porqué de la elección de la palma como símbolo de la victoria lo explica Cobarruvias en su Tesoro... ([1611] 1979: s.v.): "La palma resiste al peso y se encorva y haze arco [...]; y porque resistiendo alcanza la victoria, por esto coronan con palma a los vencedores". En este mismo sentido lo trae Autoridades en su 4. acepción (1963: s.v.): "Se toma por la insignia del triumpho y la victoria, porque los Romanos coronaban con Palma a los victoriosos [...] y ansí se dice la Palma del martyrio, y se pone por insignia de la perpetua virginidad. Cirlot (1969) atribuye a la palmera, según la cosmogonía persa, la simbología de la "tierra celeste", elemento iconográfico que retoman el arte mozárabe y románico aludiendo a los temas bíblicos. La palma es emblema clásico de la fecundidad y la victoria y, según Jung, representa el alma. El grado de galardón que se otorga a San Lorenzo en el cielo - curiosamente denominado aquí por Berceo "concejo" - es el inmediato inferior al de la jerarquía apostólica, la suprema entre los hombres: «Sacados los apóstoles que tienen mayor grado, nunqua fue el concejo con omne más pagado" (copla 199b). 


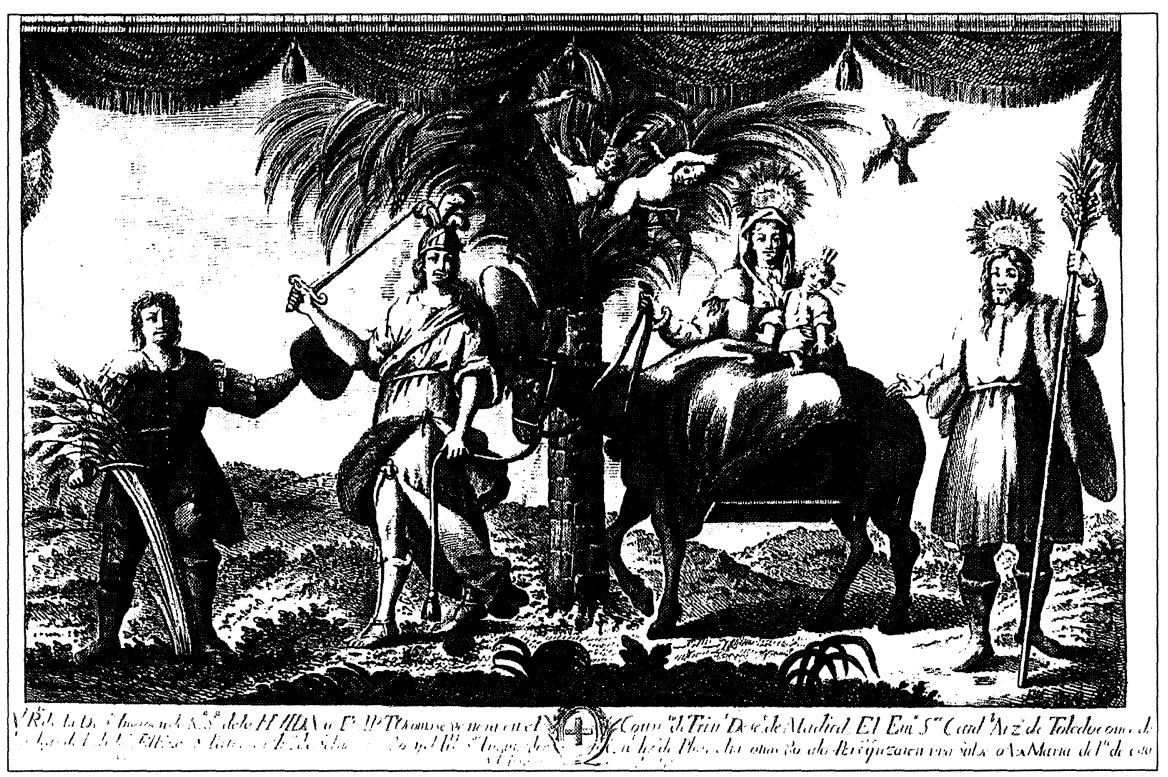

FIGURA 2.-Milagro de la palmera, tal y como se representaba en la imagen de $N .^{a} S .{ }^{a}$ de la Huida a Egipto (Madrid, Convento de Trinitarios Descalzos). Josef Brieva f', año de 1796. Col. part. Instantánea donde los personajes parecen posar para el devoto espectador.

como uno de los ingredientes del recibimiento en la gloria y meta junto a la corona y la silla. Pero, desgraciadamente, El Martirio de San Lorenzo queda interrumpido en la copla 105, en plena "asadura" del diácono. Tampoco se han conservado las fuentes directas, que podrían haber sido reveladoras en este sentido. La Passio Sanctorum Xysti et Laurentii concluye, un poco más allá que la de Berceo, con las últimas palabras del mártir al expirar, agradeciendo a Cristo el premio de atravesar las puertas del cielo: "Gratias tibi ago, domine Iesu Christe, quia merui ianuas tuas ingredi" 5 . A nosotros nos deja, tras ellas, sin resquicio de la apoteosis final donde, creemos, no hubiera faltado el galardón de la palma en su entronización celestial; ceremonial espléndidamente recogido en el Apocalipsis y en los Apócrifos: "Vi una gran muchedumbre [...] de todas las naciones, tribus y pueblos [...], de pie delante del trono y delante del cordero, vestidos de ropas blancas y palmas en las manos y clamaban [...] la salud a nuestro Dios" (Apocalipsis; 7, 9-10).

5 Passio Sanctorum Xysti et Laurentii. Ver comentarios y textos sobre las fuentes del Martirio de San Lorenzo, G. de Berceo 1971-1981: V, 164-180; esp. 174, párrafo 28. Ver igualmente sobre este martirio el comentario de Pompilio Tesauro, G. de Berceo (1992: 457-460). 
La utilización cristiana más directa de la palma como signo del triunfo parece derivar, entre otros pasajes, del Descanso en la Huida a Egipto (escena de carácter maravilloso y de iconografía tan difundida como deliciosa ${ }^{6}$ ), que trae el Evangelio del Pseudo-Mateo:

Jesús se volvió a la palmera [que había improvisado fruto y sombra a la Sagrada Familia] y dijo: "Yo te concedo, palmera, el privilegio de que una de tus ramas sea llevada por mis ángeles y plantada en el paraíso de mi Padre [...], para que se diga a aquellos que hayan vencido en cualquier lucha: Has obtenido la palma de la victoria”. Y, mientras decía esto, he aquí que un ángel del Señor apareció sobre la palmera, y tomando una de sus ramas, voló hacia el cielo con ella en la mano [...]. "Esa palmera que he hecho transportar al paraíso será dispuesta para todos los santos en un lugar de delicias" (Pseudo-Mateo; XXI, 1 y 2. Evangelios Apócrifos 1934).

Hija del pasaje anterior, la palma aparece, desde época muy temprana, asociada al tema de la Dormición o Tránsito de la Virgen como pasaporte y "compostela" ${ }^{7}$ para el cielo y anuncio de la victoria sobre la muerte. Así lo recoge el Evangelio del Tránsito de la Bienaventurada Virgen María, de Vicente Beauvais (parlamento del ángel a María, a un año ya de la Ascensión de Cristo): “... la saludó y le dijo: "De parte de Dios [...] te he traído un ramo de palma del Paraíso, y lo llevarás contigo cuando, de aquí a tres días, seas recibida en el cielo" [La Virgen a San Juan]: “... le enseñó las ropas para su sepultura y la palma de la luz que había recibido" (Evangelio del Tránsito de la Bienaventurada Virgen María; I, 2-3 y II, 5. Evangelios Apócrifos 1934) ${ }^{8}$.

Como triunfo y arquitectura, efímeros, se utilizaron las ramas de palma en la evangélica entrada de Cristo en Jerusalén el Domingo de Ramos, anuncio del ingreso del alma en la Jerusalén celestial: "Al día si-

\footnotetext{
${ }^{6}$ Hasta el siglo xIV no hemos encontrado representaciones de este pasaje.

7 Se denomina compostela a la documentación con que los peregrinos a Santiago acreditan haber cumplido sin engaño las jornadas, mereciendo así las gracias espirituales y jubileos y la exención de las penas que, de manera concertada, se redimían con este viaje.

${ }^{8}$ La simbología de la palma como atributo en la Dormición de María tiene, probablemente, su ejemplo más sobresaliente en la representación del Misteri en Elche, en la jornada conocida como la Vespra, cuando San Juan entrega a María, antes de morir, la palma de la victoria como sello de su inmortalidad. Este elemento, dentro de la iconografía funeraria, no parece exclusivamente reservado al culto y teatralización del Tránsito de la Virgen, también se incluía la palma en el aderezo y mortaja de las doncellas con fama de virtud -al menos durante los siglos XVI y XVII-, si nos atenemos al dicho recogido por Correas en su Vocabulario (1924): "Guirnaldas a los niños difuntos y palma a las mozas. Por triunfo de su castidad.
} 


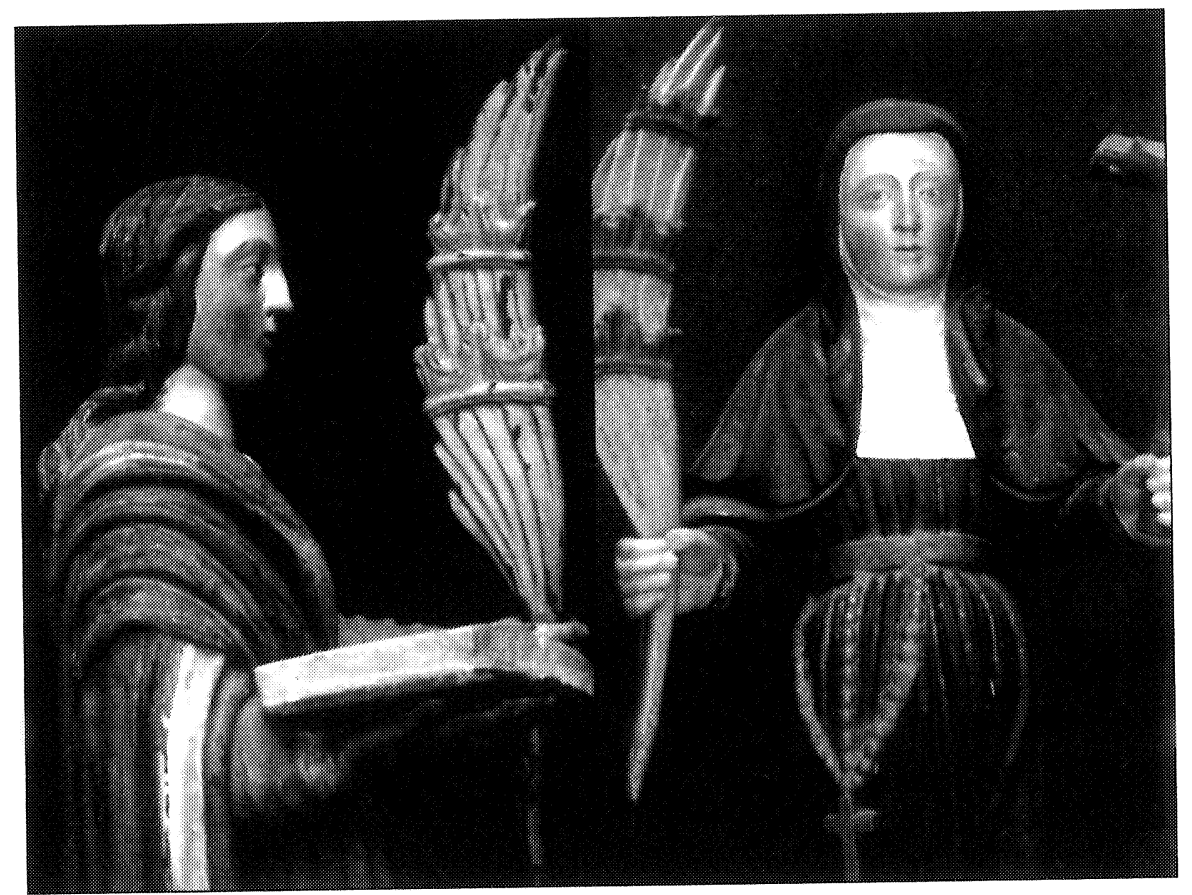

Figura 3.-San Juan Evangelista (¿?) y Santa Rita con el atributo de las coronas enfiladas en la palma (Parroquial de Santa Baya do Este - Pontevedra-, ss. XVII-XVIII). Foto A. Cea.

guiente, la gran muchedumbre que había venido a la fiesta [de la Parasceve], al oír que venía Jesús a Jerusalén, tomaron palmas, y salieron a su encuentro y clamaban: ¡Hosanna! Bendito el que viene en el nombre del Señor, y el Rey de Israel" (Juan; 12, 12-13) ${ }^{9}$.

En la obra de Berceo la palma es como un peón invisible que solo se intuye una vez en la Vida de Santo Domingo de Silos, en el pasaje de la entrega de las tres coronas por los ángeles, donde concluimos por deducción iconográfica que el Santo de Cañas, al no ceñirse las sienes con ellas, las recibió enhiladas en una palma. Entre los nombres de árboles y frutos bíblicos con que se compara a la nueva Eva en Los Milagros de Nuestra Señora (39cd) está el de "palma bien ajumada" y "piértega en que sovo la serpiente alzada", letanías pintadas alrededor de la Tota Pulchra como gloria y guirnalda.

${ }^{9}$ En Mateo; 21,8 se dice: "otros cortaban ramas de los árboles, con ellas tapizaban los caminos". En Marcos; 11, 8: "Y muchos tendieron sus mantos en el camino y otros follaje, cortado de los campos". El evangelista Lucas 19, 34, solo alude a la guarnición de mantos con que engalanaron el pollino, nunca montado por hombre, sobre el que subió Cristo. 
La corona como elemento y rango celestial presenta dos facetas que tienen un único fin para el hombre de vida santa. Por una parte, simboliza el poder y la potestad reales, la auctoritas, conceptos emblemáticos que se fijan en la iconografía cristiana -sobre todo a partir del período bizantino y se mantienen con abundantes ejemplos a lo largo de la Edad Media y hasta bien entrada la Moderna- para escenificar el momento de la coronación en el cielo: del Padre Eterno al Hijo, de María por la Trinidad y coronaciones de santos. Esas mismas deidades aparecen en las apoteosis reales, representaciones que legitiman la realeza terrenal que deviene de la divina.

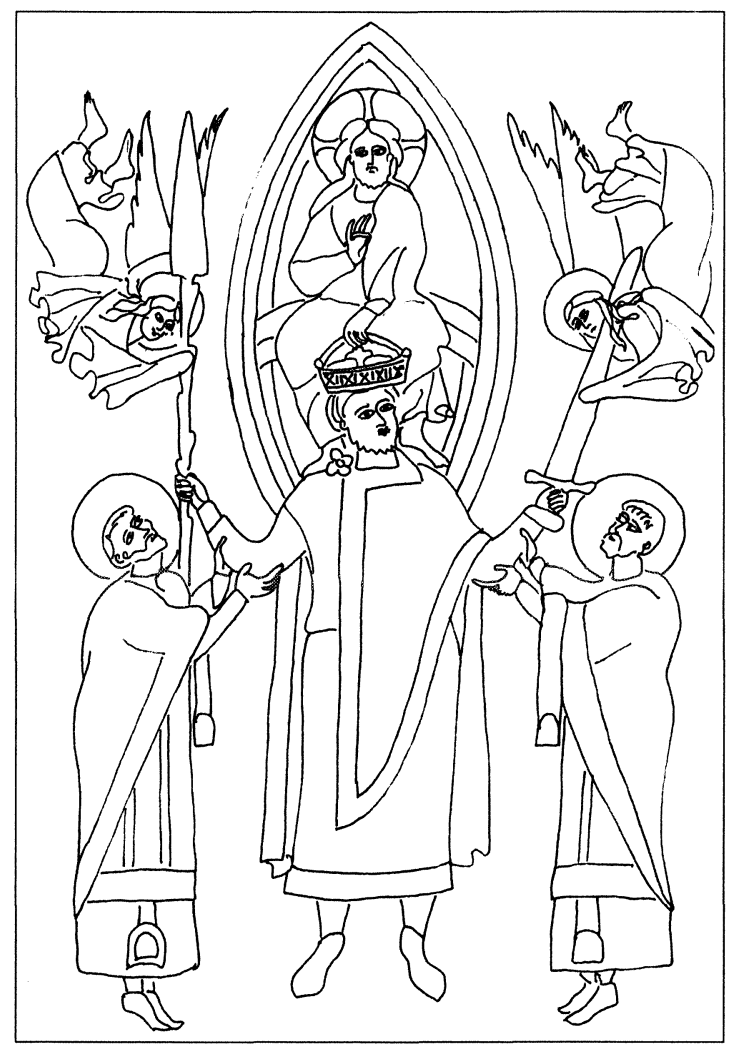

FIGURA 4.-Apoteosis de Enrique II coronado por Cristo. Ratisbona, Sacramentario de Enrique II, entre 1002 y 1014 (München, Bayerische Staatsbibliothek). Dibujo de A. Cea.

El ceremonial y la imposición de ese atributo sobre las cabezas de los reyes tiene como protagonista la mano diestra divina, que actúa desde una nube y es asistida por dos ángeles acólitos de la primera jerarquía (generalmente querubines y serafines), ritual que se refuerza a veces con el lema: per me reges regnant. Este protocolo y corte manifiestan, a la vez, una ambivalencia celestial y terrenal: Escenografías mixtas de cielos con arquitecturas áulicas si se representa en la gloria la coronación como galardón del alma, o nubes y divinidades que irrumpen en escenarios de la tierra y se mezclan con personajes de este mundo. De manera que los reyes se divinizan participando de la suprema majestad de Dios y éste actúa y toma la 


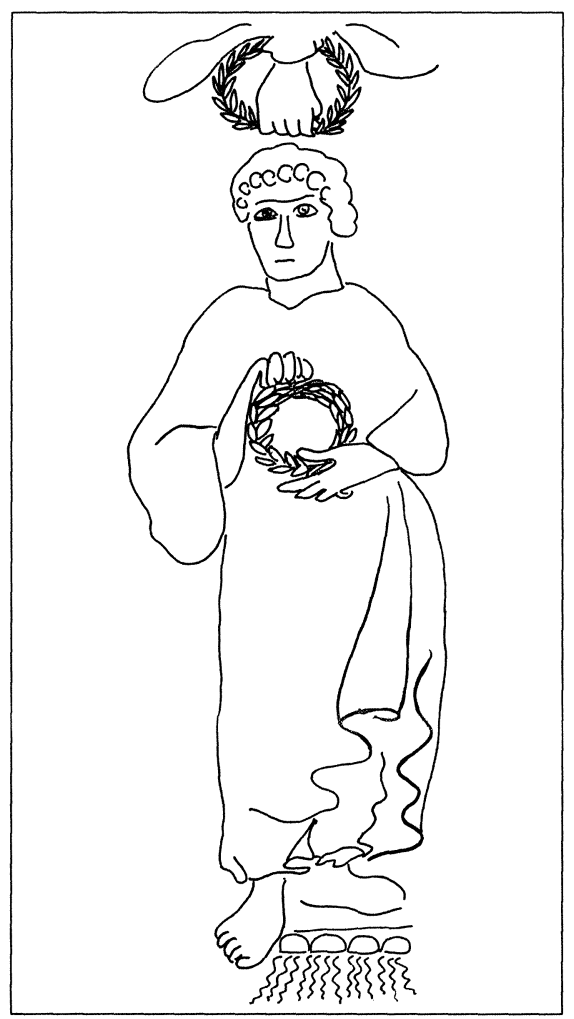

Figura 5.-Coronación de Cristo por el Padre + Cristo mostrando su trofeo sobre los cuatro ríos del Paraíso. Detalle del relicario de plata conocido como capsella africana (Museo Vaticano, ss. v-vI).

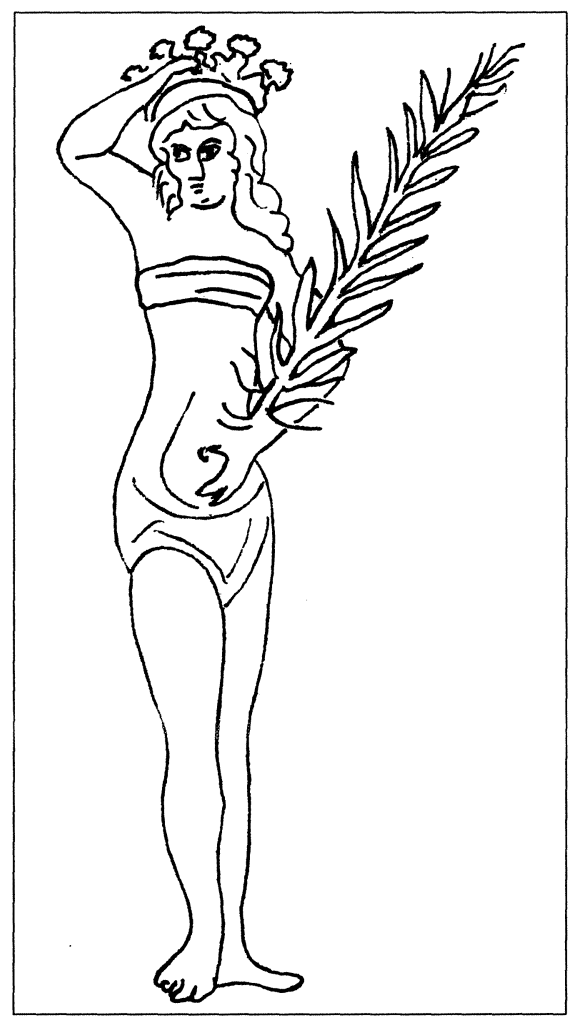

FIGURA 6.-Muchacha atleta premiada con la corona y la palma. Detalle de mosaico de pavimento (Sicilia, villa en Piazza Armerina, s. IV). Dibujos de A. Cea.

apariencia de rey de carne y hueso. El premio consiste en hacer de las almas gloriosas reyes menores coronados en la corte celestial.

La corona se toma, además, por conseguido triunfo victorioso del que llega al final de la vida - carrera agónica- y consigue a pulso el cielo, según expresión paulina: “iNo sabéis que los que corren en el estadio, todos, sin duda, corren, mas uno solo recibe el premio? De tal modo corred que lo alcancéis. Y todo el que toma parte en el certamen, de todo se abstiene; y ellos, al fin, lo hacen por obtener una corona que se marchita; mas nosotros, una que no se marchita" (1 Corintios, 9, 24-25) ${ }^{10}$.

${ }^{10}$ Cito por Bover-Cantera (Madrid: BAC, 1961, 6." ed.). Para los Evangelios Apócrifos sigo la edición de E. González Blanco (Madrid: Librería Bergua, 1934). 
El pensamiento cristiano sostiene como modo más certero y corto para ganar la carrera y corona del cielo el camino del martirio ${ }^{11}$; así lo expresa Berceo en El Martirio de San Lorenzo (copla 72 ad): "Ante de quinto día [...] ganarás grand corona, mejor de oro puron. Remedando el pasaje de Cristo en Getsemaní, se recuerda a este mártir la necesaria agonía y el trago amargo del cáliz de su pasión, para alcanzar los galardones de la victoria $(73 \mathrm{abc})$ :

\begin{tabular}{|c|}
\hline $\begin{array}{l}\text { Quanto ayas el vaso } \\
\text { luego serás connusco } \\
\text { enna corte del Cielo }\end{array}$ \\
\hline
\end{tabular}

La corona suele representarse como trofeo de formas vegetales y hechura de materiales preciosos: oro, plata, gemas, con la que Dios ciñe las sienes del vencedor o del afortunado. Este doble aspecto -el de victoria conseguida en lid y el de dominio heredado por estirpe (en lo espiritual por filiación divina) - armoniza, a lo largo de la tradición literaria y artística hasta hoy, bajo un mismo símbolo, materializado en la corona.

En la obra de Berceo y especialmente en Los Milagros de Nuestra Señora, las imágenes que representan a Santa María y al Salvador aparecen coronadas y repartiendo ayuda o justicia como en una corte de la época. Pero también despunta el tema del amor cortés a lo divino cuando se invoca a Nuestra Señora como a la Dama de los pensamientos, y la devoción bernardina a la Virgo Santa y Gloriosa, a la que ahora se aclama no solo como a madre de Dios - teotokos — sino también, de manera manifiesta (así se lo pide este santo), como madre de los hombres: "monstra te esse matrem" 12 .

${ }^{11}$ Curiosamente, en el romance de Delgadina, la idea de la corona como triunfo y premio en la carrera - dispuesta por el padre incestuoso para el más rápido de los criados que acerque el agua a los labios de la moribunda Delgadina - es como un contrafactum martirial, conceptos que se oponen a los de fracaso/decapitación de los vencidos: "Los que primero llegaren, la corona se ganaran, los que postreros llegaren, la cabeza les cortara" (Versión de San Esteban de la Sierra, recogida de Consolación Labrador, de 82 años en 1979); “...el que primero llegara la corona se ganara, el que postrero llegara la cabeza le cortara". (Coinciden las dos versiones que recogimos en San Esteban de la Sierra a Emilio Rosingana, de 100 años, y en Lo Llano a Hilaria, de 89, en 1979); "el que primero llegare, la corona tien ganada, el que el último llegare, la cabeza tien cortada" (Versión de Miranda del Castañar, recogida a Adela Novoa, de 87 años, en 1983). La corona es el símbolo por antonomasia del poder y en ese sentido lo trae Correas (1924) cuando dice: "Bien se está San Pedro en Roma, si no le quitan la corona" (refiriéndose a la tiara).

${ }^{12}$ Son varios los pasajes en Los Milagros de Nuestra Señora donde Cristo y María son denominados rey y reina o coronados: "Reina de los Cielos" (copla 659a); "Díssoli 


\section{La Virgo coronada en Los Milagros de Nuestra Señora}

Senora benedicta, Reína acabada, por mano del tu Fijo don Christo coronada (746 ab)

Como ya anticipábamos, en diferentes ejemplos de Los Milagros aparece fijada con claridad la iconografía coronada de Santa María con el Niño en los brazos, efecto ya de la costumbre de revestir las imágenes sagradas con elementos de poder y ropas, anacrónicos y realistas, a la manera de los reyes terrenales, tradición mantenida hasta hoy ${ }^{13}$. Estas representaciones regias de Cristo y la Virgen son espejo donde el cristiano ve lo que le espera en el cielo.

En el milagro de "La abadesa preñada" (III-21, copla 564c), Nuestra Señora, cuando viene en auxilio de la monja, aparece como "la Virgo Coronada" ${ }^{14}$. No ahorra Berceo detalles en el milagro de "La iglesia robada" (III-24, copla 716) sobre la indumentaria y atributos de la imagen de Santa María que presidía el altar del sacrilegio.

Ternié en la cabeza corona muy onrrada, de suso una impla, blanca e muy delgada, a diestro e siniestro la tenié bien colgada, asmaron de tollérgela mas non ganaron nada ${ }^{15}$.

el judío: "Señor rey coronado" (782); "La Reina de Gloria, Madre Sancta María" (856); "Señora venedicta, Reina coronada" (818); "Tollióseli delante la Reina preciosa" (864); "Madre del Rey de Gloria" (875); "La Madre gloriosa, de los cielos Reina" (910). Además de los de: "Sennora gloriosa" (669a); "Virgo gloriosa" (702b); "Gloriosa" (5 veces, coplas: 642d, 654c, 661c, 672a, 697d). "Sancta María" (669a), "nuestra Dama" (650b) y Madre: "madreziella" —en boca del prestamista judío- (687b), "buena Madre" -invocada así por el mercader de Bizancio- (688b), "Madre del pan de trigo" (659a), o la invocación con el apellido topográfico de "Madre santa la de Rocamador" (664d).

${ }^{13}$ Sobre la antigua costumbre de adornar las imágenes, especialmente las de Nuestra Señora, con joyas y ropas como personas de carne y hueso, ver en Cea (1992: 41-47).

${ }^{14}$ La corona como símbolo de la gracia glorificada de María suele ser atributo necesario en las imágenes vestideras junto con la medialuna. Así viene expresado en la Danza del Cordón para la festividad de Santa María de Lo Llano, cuando cantan las mozas de ramo la siguiente estrofa:

Tienes la corona de oro,

la medialuna de plata,

como eres Madre de Dios

tienes el alma tan guapa.

(Recogida en Santibáñez de la Sierra, Salamanca, a Primitiva Berrocal, de 52 años en 1979).

15 Por *onrrada" habrá que entender probablemente lo que en textos posteriores (siglos XVI-XVIII) exige la Iglesia en los mandatos de Santa Visita para sus imágenes: 
En el milagro del "Mercader de Bizancio" (III-23, coplas 692 y 702) ofrece Berceo algunas variaciones que se apartan considerablemente de la fuente original. Los versos 692ab presentan una imagen perfilada con claridad, además de coronada, como glicophilousa: "Paráronse delante al Ninno coronado, el qe tenié la Madre dolzement abrazadon; iconografía que vuelve a señalarse en la copla 649abc: “... mostroli [al judío] la imagen, la de Sancta María, con su Fijo en brazos, la su dulz compannía" ${ }^{16}$. El texto latino matriz no dice "Ninno coronado", sino solamente: "Ihesu Christe" (33r).

Además de alterar la iconografía de Cristo se duplican los divinos protagonistas, amplificatio que ya comenta Dutton: "Berceo hace que sean fiadores Madre e Hijo, mientras en el latín solo se trata del Hijo" (Dutton, 1971-1981: II, 201) ${ }^{17}$.

No queremos pasar por alto el topos, tantas veces repetido en la literatura culta y popular, de las imágenes santas que prodigiosamente se mueven y hablan para testificar: “... qe fabló la imagen, la su vertud preciosa" (697b). En la fuente latina se dice: "mirabile dictu, ymago respondit" $\left(33^{v}\right)^{18}$. Concluye Berceo este milagro, en las coplas 701-702, presentando

"decoro". La corona que adornaba esta efigie debía de ser de una riqueza material y formal que le pareció muy digna a Berceo. Debajo hermoseaba el rostro de María una toca blanca de hechura y calidad extraordinarias, quizá de seda "muy delgada" y dispuesta con gracia y simetría por parte del muñidor que cuidaba de la imagen, de modo que caería sobre los hombros, no más de un lado que del otro, a manera de mantillina.

${ }^{16}$ Con el paso del tiempo, en la relación devocional imagen/devoto, la importancia del papel de María oscurece la figura de Jeșús, al que sostiene en sus brazos, mientras ella se convierte en personaje principal, absoluto y único, en detrimento del pequeño niño, que llega a hacerse prácticamente invisible bajo la indumentaria de la Madre - apenas asoma la cabeza- hasta desaparecer en los siglos XVIII y XIX.

${ }^{17}$ Advertimos como curiosidad un probable lapsus de Berceo, entre las coplas 689 y 690, seguramente debido a lo que en el arte de afrescar se conoce como giornate. Los versos 653ab refieren a una imagen de Nuestra Señora con Niño, haciendo de testigo del mercader: "buenos testigos tengo" (689b). Debió de terminar nuestro autor aquel día su tarea en esa copla (653), transcurriendo algunas jornadas hasta que retomó su trabajo. Olvidó aquella imagen, sin advertirlo, y pasó a la de un Crucifijo, según expresa la fuente latina que dice: "Fabló el crucifixo, díxoli buen mandado" (694a).

${ }^{18}$ Es este un ejemplo muy temprano de mirabilia, donde la imagen sagrada que habla o gesticula se presta a testificar y ser fiadora -aquí del cristiano contra el truhán (653)—: "díssoli el burgués: "Sennor tan acabado departi esti pleito". (692cd). Se expresa, además, la fórmula gestual del contrato: "a Madre e a Fijo metiógelos por mano" (653ab). Nos interesa subrayar también la incredulidad ante el icono, de quien advierte en él solo un trozo de madera, incluso su especie; topos y situación que quedan incorporados como motivo folklórico: "Cuidó qe la imagen qe non habié sen- 
la figura de cierto arcediano viajero, que un día topó en su camino con la celebración de este milagro e imagen, cuya historia, a petición suya, le contaron; él, a su vez, "metiólo en escripto". El poeta emilianense le despide con una personal y hedonista fórmula de galardón celestial: "deli Dios paraíso e folganza sabrosa", cuando en el texto latino solamente se dice: "Omnibus suam sanctam genitricem vere colentibus subvenietis" (el subrayado es mío).

El ceremonial de entronización y coronación del bienaventurado que sube al cielo tiene en la figura de María, como síntesis de la perfección humana divinizada, su ejemplo prototipo y supremo, protocolo que viene recogido con abundancia en textos literarios, canciones, dramatizaciones sacras e iconografía, y que describe así Ribadeneyra (1790: 484-486):

\begin{abstract}
Allí fue colocada a la diestra de su Hijo, en un trono aparte, y por si sobre todos los Coros de los Ángeles [...]. Se comenzó una Solemnísima Procesión y un triunfo [...] desde el sepulcro a lo más alto del cielo y hasta el Trono de la Santa Trinidad [...]. Fue presentada por el Hijo delante del Padre y recibida de él como esposa dulcísima y Templo suyo y coronada de gloria y constituida Emperatriz del Universo y Reyna y soberana de todas las criaturas: Sentóse como otra Bethsabé, madre de Salomón, en una silla al lado de su Hijo sobre todos los Coros y Jerarquías de los celestiales Espíritus y de todos los Santos. Aquí vinieron aquellos divinos Cortesanos a bacer reverencia y dar obediencia a la Reyna [...] reconociéndola [...] por su Señora y de todas las criaturas [...] pues veían que por su medio babian sido reparadas sus sillas [...] y que justamente aquella corona correspondía a sus victorias. (El subrayado es mío).
\end{abstract}

En el políptico de San Bavón de Gante y acorde con esa visión medieval, Hubert Van Eyck presenta, sentados en la parte superior de la tabla central, a los tres protagonistas de la deesis: En el medio, el Padre Eterno, vestido de pontifical y a los lados, según norma, María y San Juan Bautista hacen tiempo, entretenidos en lecturas sagradas, para el momento de la coronación de las almas que alcanzan la gloria en medio de una arquitectura de triunfo. Bajo el escabel del Padre está preparada la corona de oro y piedras preciosas instrumento del ritual (María tiene ya ceñida la suya propia de flores) y escrito a sus pies, creemos, el texto que se utiliza en el ceremonial.

El que impone la corona antes de ceñirla sobre las sienes del que la espera arrodillado señala con ella sobre la cabeza una cruz: desde la nuca a la frente y de izquierda a derecha, al tiempo que recita la siguiente fórmula:

tido, non fablarié nada" (690cd). "Fueron a la eglesia [...] facer esta pesquisa [...], fueron tras ellos muchos e muchos delanteros [curiosos], veer si avrién seso de fablar los maderos" (691abcd). Sobre este tema ver en Cea (1992: 17 y 26-27). 


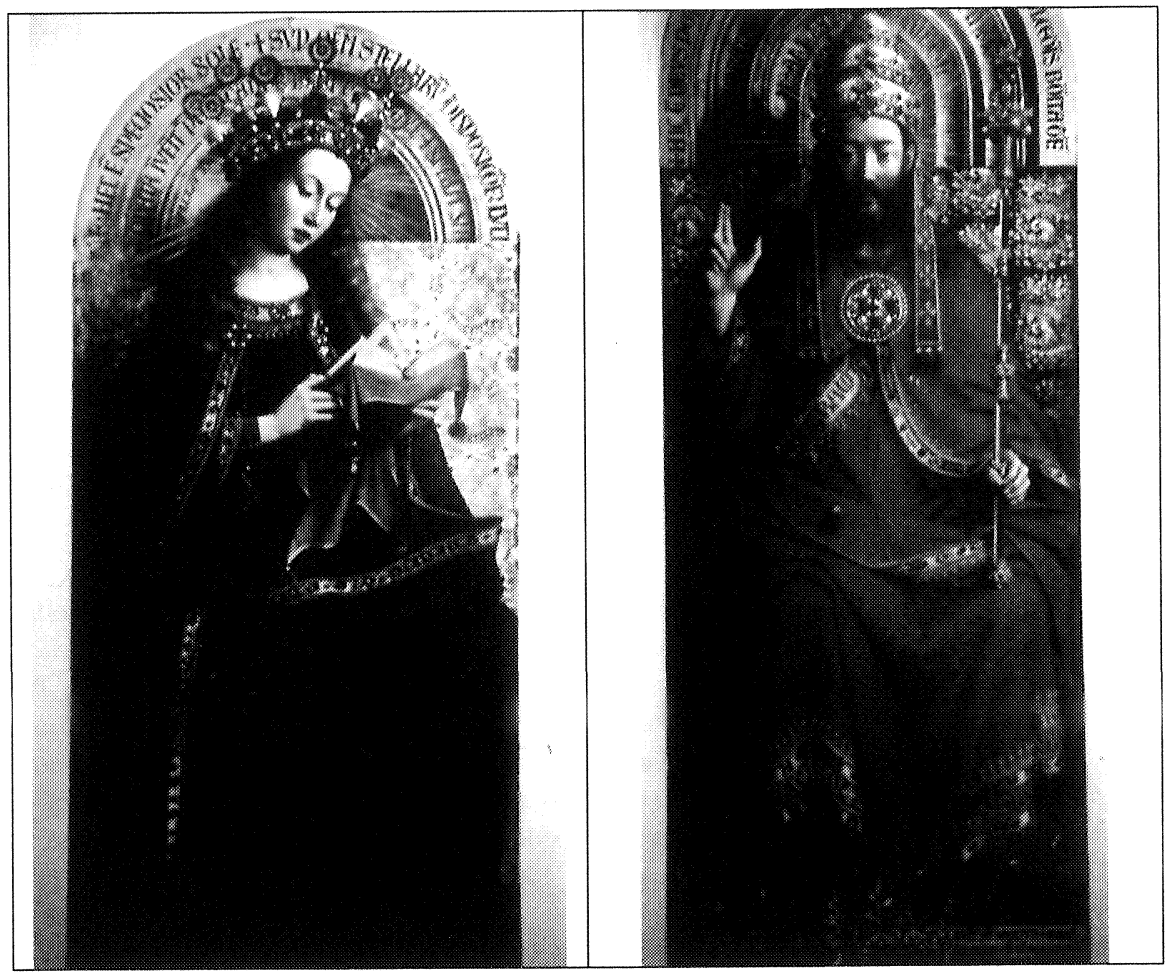

FiguRA 7 a y b. - La Virgen coronada y el Padre Eterno. Detalle del Cordero místico. Jan y Hubert Van Eyck, c. 1430 (Políptico de San Bavón de Gante).

VITA SINE MORTE IN CAPITE

IUVENTUS SINE SENECTUTE IN FRONTE

GAUDIUM SINE MERORE A DEXTRIS

SECURITAS SINE TIMORE A SINISTRIS

Las jerarquías celestes y terrenales asisten expectantes con sus atributos a esta detenida apoteosis de la glorificación porque han bebido de la fuente de la gracia y del cáliz donde cae la sangre del cordero de Dios, figuras representadas en la parte inferior del políptico sobre un locus amoenus $^{19}$.

${ }^{19}$ Esta representación gráfica no debía extrañar a un público familiarizado con el romance de La sangre de Cristo, pues la tendría presente cada vez que lo cantaba o recitaba, recordándole al final el galardón de la corona. 


\section{El cielo y la corona en la Vida de San Millán}

Las coplas 301d a 308 describen la asunción por los ángeles del alma de San Millán y el recibimiento con cánticos, grandes procesiones y "fiesta doble" o principal, que culminó en ofertorio por parte de las jerarquías de santos, quienes dieron muestras de alegría a su llegada con expresiones apenas contenidas: "non podrién mayor gozo aver nin demostrar" (307c). Jerarquías cuyo orden, de abajo arriba, se clasifican de la siguiente manera: confesores, patriarcas, apóstoles, mártires y vírgenes, única escala que se describe aquí coronada: — - Todas con sus coronas la vinién visitar [al alma]" (307b) —, precediendo al Rey de los cielos y a la Gloriosa, que desfilan en la procesión en último lugar, como corresponde a su rango ${ }^{20}$. Parece que Millán ocupó su sitial entre los confesores, cuyo grado ven muy mejorado con esta nueva adquisición: "Todos los confesores facién grant alegría, porque vinié tal omne entre su compannía" (303 ab).

Después tuvo lugar la toma de posesión entronizada (aparece ya aquí la silla como primer galardón) y coronación del alma de Millán:

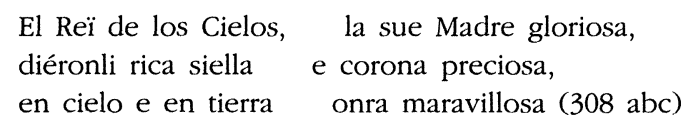

Se sirve Berceo (en el verso c) de una fórmula ya entonces vigente - "en el cielo y en la tierra" - y que se ha conservado hasta hoy al final de ciertas oraciones, imprecaciones y romances como llave, cuya recitación mágico-religiosa tiene el poder de alcanzar para quien la rece, al mismo tiempo que bebe del cáliz sagrado, las dos coronas, terrenal y celeste:

El hombre que la bebiere será bienaventurado,

en esta vida será rey y en la otra coronado.

El que esta oración dijera todos los viernes del año sacará un alma de pena y la suya de pecado ${ }^{21}$.

\footnotetext{
${ }^{20}$ No mantiene aquí Berceo el mismo número ni el orden de jerarquías que en el Poema de Santa Oria, donde se presentan de la siguiente manera: confesores (realmente elude este término y lo desglosa en calonjes y obispos; también debería incluir aquí a los ermitaños), vírgenes, ermitaños, mártires, apóstoles, identificados, además, por su indumentaria y atributos. Este fenómeno se debe, quizá, a las distintas fuentes que utiliza para sus Vitae. Berceo, como si solo accediera a una gloria menor, elude siempre las jerarquías angélicas en los cielos que presenta.

${ }^{21}$ Es la versión recogida en San Esteban de la Sierra a Emilio Rosingana, de 100 años, en marzo de 1977 y corresponde a los versos 24-27 del romance El discípulo
} 
La Vida de Santo Domingo de Silos

a) El puente de cristal + las tres coronas prometidas

De excepcional belleza resulta el espacioso pasaje (coplas 228-245) donde el abad Domingo confiesa en confidencia al círculo más cercano de frailes — "los más familiares" - su sueño visionario del puente de cristal, tras el que dos ángeles le muestran anticipadamente la triple corona, reservada como premio a sus buenas obras; "confesión" que deberán mantener en secreto hasta su muerte: "fasta salga mi alma desta carnal presón" (247d). Berceo parece presentar literalmente el celestial rito de paso del alma de Domingo, que se inicia al cruzar un pavoroso río, con todas las connotaciones que caracterizan al clásico Leteo, por donde el alma navega hacia el más allá (copla 230). La visión se decanta en la copla 230, al deslindar el mal del bien con el ejemplo de la bifurcación del gran río o lateralización: el de las buenas obras, "blanco [...] como piedras cristales", y el izquierdo o caudal de los pecados, descrito aquí con color de infierno: "plus vermejo que vino de parrales" (cd). Del río blanco nace un puente de cristal — -de vidrio era non de otra madera»; es el camino estrecho del bien obrar y carrera de salvación, las moradas ascéticas, variante simbólica de la scala caeli que se desarrolla en las coplas 231, 235 y 236. Ve nuestro santo, al final del puente y de las gradas que lo remontan, apostados, parece que dos ángeles. Uno de ellos se diferencia por sus ropas albas —dixo el blanqueado" (237a)—, ambos con rica indumentaria: "almátigas blancas de finos ciclatones, los pechos orfresados, mangas e cabezones" (232cd) y calificados como "barones" (232b), "tan honradas personas" (233a) y "mensajeros" $(240)^{22}$. Personajes que el abad

amado + El Bautismo + La Sangre de Cristo. La versión cantada en Garcibuey por Edita Martín Andrés, de 73 años, y Encarnación Andrés, de 71 (junio de 1979), dice: "...en la tierra será rey y en el cielo acoronado" (sic). En algunas variantes, como la de San Esteban de la Sierra, se amenaza y conmina a quien, sabiendo esta oración no la diga y oyéndola no la aprenda: "El que la sepa y no la diga, el que la oiga y no la aprenda, verá el día del Juicio lo que a su alma le espera", o "lo que se contiene en ellan, según la versión albercana que recitó Marcelina Hernández Martín, de 80 años, en abril de 1986. En realidad se están contraponiendo dos juegos de términos, positivos unos: aprendizaje-recitación $=$ corona y premio, y los otros negativos: no recitación-olvido $=$ Juicio final y castigo.

${ }^{22}$ Berceo no escatima los lujosos detalles en las ropas de estos ángeles, refiriéndose en concreto a las dos piezas más llamativas, los camisones, que serían, como era usual y según su rango, de lino de primera calidad con guarnición orfresada en sus extremos - cabezones de escote cuadrado y bocamangas- "a uso de nobles". Como "Sobretodos", dalmáticas blancas de seda hasta media pierna con hendiduras laterales. 
de Silos no parece asociar con la iconografía angélica que él conocía y a los que da tratamiento de "señores" (239a); ellos a él, de "fraire" (237a). Al cabo de este paso le dan la bienvenida mostrándole el "mandado" que traen de parte de Dios: las tres coronas (uno de ellos porta dos y el otro la tercera) con que se adornará en el cielo si mantiene sus virtudes.

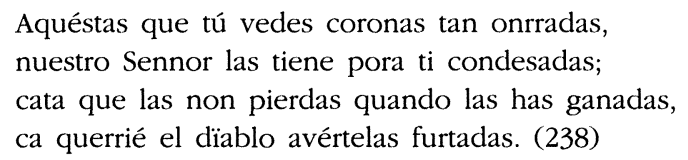

Según se deduce de este pasaje, hay una linde muy angosta entre el bien y el mal, entre el premio y el castigo, el infierno y el cielo, el santo y el diablo (robador de coronas), el vicio en el pecador y la virtud en el monje. Esta que al principio resultaría tan heroica en Domingo, al final, parece ya virtud acostumbrada, si nos atenemos a la mágica clave que le dejan caer los ángeles: "si tú perseveras en las mañas usadas, tuyas son las coronas (243ab)".

La espléndida y pormenorizada descripción del trofeo ocupa las coplas 233 y 234 :

\footnotetext{
La una d'estas ambas tan onrradas personas, tenié enna su mano dos preciosas coronas, de oro bien obradas, omne non vio tan bonas, nin un omne a otro non dio tan ricas donas. El otro tenié una, seis tantos más fermosa, que tenié en su cerco mucha piedra preciosa; más lucié que el sol tant era de hermosa, nunqua omne de carne vío tan bella cosa.
}

A las razones que demanda el santo, dan cumplida respuesta los dos ángeles ${ }^{23}$ en las coplas 240 a 242 . Cada corona es símbolo y colofón de

${ }^{23}$ Según Manuel Trens (1947: 429-434) la triple corona se utiliza en época gótica para expresar la apoteosis de María y su hegemonía sobre las tres principales jerarquías de santos: apóstoles, vírgenes y mártires. Esta fuente iconográfica derivaría, según el autor, del Speculum humanae salvationis en el pasaje que dice:

Templum Salomonis habuit pinacula tria,

per quae signatur triples aureola in Maria.

En Italia hay ejemplos singulares, como las advocaciones de Loreto o la Madonna d'Oropa, que se adornan con la triple corona. El propio Trens alude también al gesto iconográfico de "La mano del Niño en la corona de María" (Ibid: 599-602), postura vulgarizada a principios de época gótica y cuyo ejemplo más antiguo parece ser el de una Virgen coronada del siglo vill que se conserva en un mosaico de Capua. La 
una virtud. La primera por ser buen fraile (casto y obediente), las otras por revitalizar -material y espiritualmente- dos monasterios: el arruinado de Santa María de Cañas y el de San Sebastián de Silos, donde era abad. Probablemente bajo el perfil de un Santo Domingo restaurador de iglesias y monasterios se pretende premiar la figura universal del defensor de la Iglesia, en aquel tiempo tan amenazada:

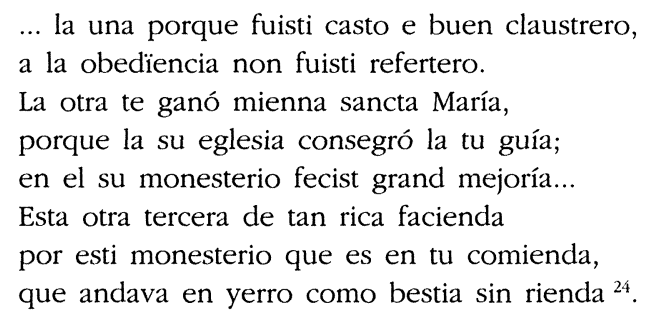

Recoge la copla 244 las sensaciones, gestualidad y propósitos que tiene el santo cuando desaparece la visión como arrancada de sus ojos: vuelta

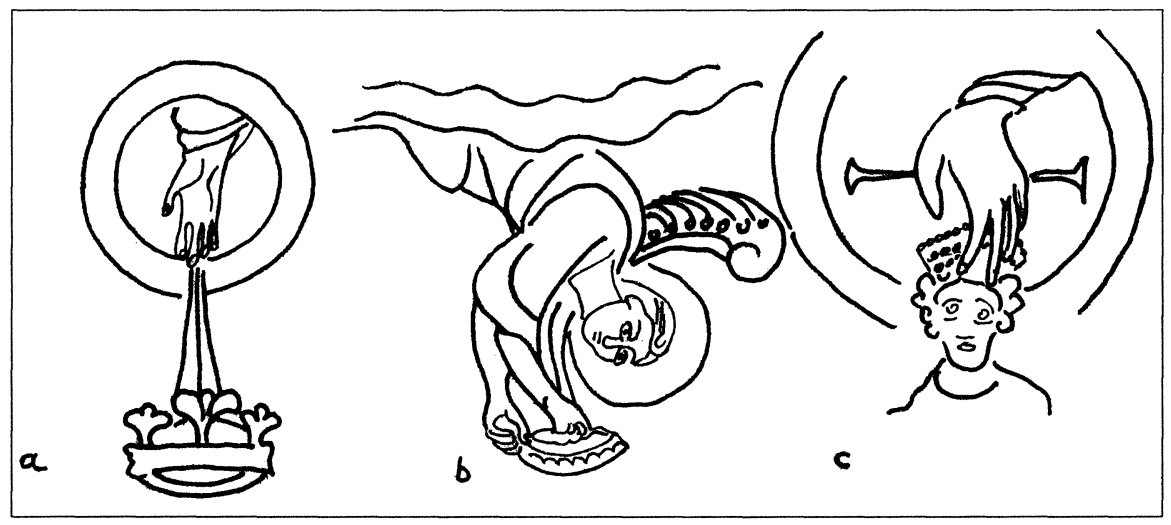

FIGURA 8.-a) Detalle de la coronación de la Virgen en su Dormición. Winchester. Pontifical del arzobispo Roberto, finales del s. x (Rouens, Biblioteca Municipal); b) ángel coronando a María en su Presentación en el templo. Detalle del Leccionario de Salzburgo, mediados del s. XI (N. York, Morgan Library); c) apoteosis de Otón III. Reichenau, Evangelios de Lluthar, c. 990. Detalle (Catedral de Aquisgrán). Dibujos de A. Cea.

triple corona o tiara, que hoy se considera atributo exclusivo de los pontífices romanos y cuya imagen prototipo es la figura de San Pedro, viene usándose solo desde finales del siglo $\mathrm{XV}$ o inicios del $\mathrm{xVI}$.

${ }^{24}$ Ese monasterio de Cañas que el santo restaura y por el que se hace merecedor de la segunda corona es hoy una humilde ermita en honor a Nuestra Señora, con un retablillo del siglo xviI, cuyo lienzo central reproduce este pasaje de las tres coronas. 
al estado de vigilia, persignamiento con que inicia y concluye el cristiano toda buena obra y conversión. Quedan como lema y recordatorio para reforzar su voluntad los versos 245cd:

si fuéremos leales a Dios e derecheros, ganariemos corona que val más que dineros.

A propósito de este relato confidencial surge, una vez más, el tema de la veracidad en la transmisión oral y escrita, que tantas veces aflora en la obra de Berceo. Nuestro autor, refiriéndose en concreto a la vita de Santo Domingo, cuenta cómo, quienes fueron testigos directos de esta "estoria", valoraban hasta tal punto la objetividad, que no añadieron ni quitaron nada, según reza la copla 227cd: "sabemos que en ello toda verdad dixieron, nin un vierbo menguaron nin otro ennadieron".

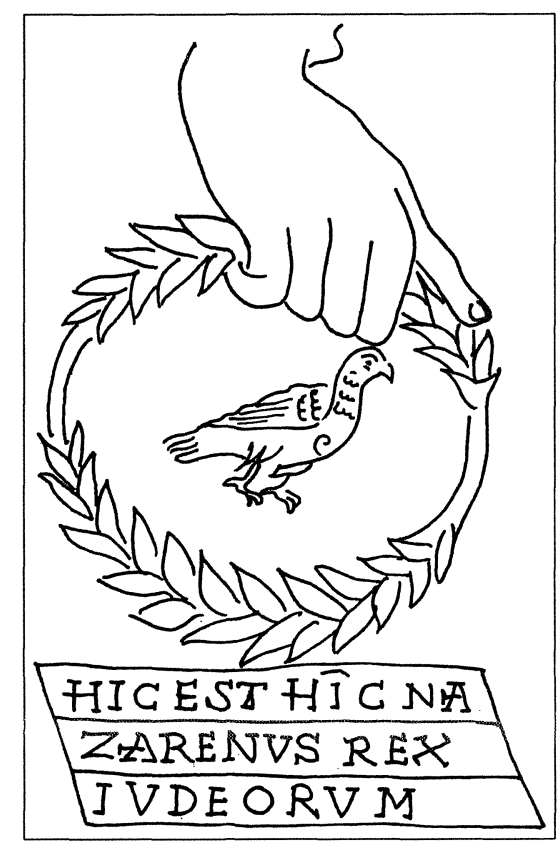

FIGURA 9.-La mano derecha del Padre y el Espíritu Santo coronan al Hijo sobre el letrero de la cruz, como confirmando el carácter regio de este texto formulado por escarnio. Detalle del reverso de la Cruz de Lotario, c. 1000. Oro con labor incisa (Tesoro de la catedral de Aquisgrán). Dibujo de A. Cea.

b) La muerte y el premio del santo

Describe Berceo en las coplas 521d-526 la muerte de Santo Domingo, la subida del alma y lo que sucede con ella:

- Bajan los ángeles a recogerla rodeándola y transportándola hasta el cielo. Allí recibe el triple prometido galardón: "diéronli tres coronas de muy grand resplandor" (522c). No se dice que hubiera ceremonia de coronación, seguramente las recibió enhiladas en una palma, pasando a ser atributo y credencial celeste en su mano izquierda. Así pues, el ritual de coronación que vimos en la Vita de San Millán, aquí se omite. Aunque en la iconografía general de los santos entrados en religión, las tres coronas son atributo de sus tres virtudes obligadas por votos de pobreza, obediencia y castidad, en la particular del Santo de Cañas, como vimos más arriba, se quieren señalar aspectos personales de su hagiografía por los que merece el galardón de Dios: la perfección de su vida monacal y 
la ayuda al fortalecimiento de la Iglesia, en la reconstrucción de los ejemplos ya mencionados de Cañas y Silos.

- Viene a continuación el recibimiento, cuando entra Domingo en la gran sala celeste, por parte de las distintas jerarquías de santos, clasificación que en este caso se rige por la norma iconográfica, enumerándose de mayor a menor rango en el siguiente orden: patriarcas, apóstoles, mártires, confesores y vírgenes.

- Es aceptado el santo y se sienta en el bando de los confesores —escapulados o monjes "q'aburrieron el sieglo" (525b)—, entre los que destaca su paisano y superior San Millán, del que con gracejo, dice Berceo, hizo policía del espacio que iba a ocupar Domingo: "por onrar su criado facié todo asseo" (526c). Este destino eterno de Domingo, dentro del grado de confesores, debería desencantar al lector si se recuerda el perfil, como ángel predestinado, con que se pinta al santo en trampantojo a lo divino en la copla 120: "Dioli tamanna gracia el Reï celestial, que ya non semejava creatura mortal, más o ángel o cosa que era espirital, que bivié con ellos en figura carnal".

- Cada uno de esos órdenes celestiales es descrito desempeñando distintas actividades ocupacionales, al menos en el recibimiento del alma de Domingo: Los patriarcas, apóstoles y mártires atodos eran alegres con él e plazenteros" (523d). Los confesores y las vírgenes, como en coros enfrentados, le honraron con salmodias y cánticos, liturgia que aquellas, además, organaban "dulcement" (524). Parece que el coro de frailes, "aunque mucho pagados con esti monjen, permanece a su aire, y como de guardia ipara que, mientras, no quedara desatendida la majestad divina?, cantando "a Dios laudes, sones multiplicados" $(525 \mathrm{~cd})$. Curiosamente, solo la jerarquía de los "escapulados", que deberían ser sus principales anfitriones, se alejan de este recibimiento — siendo Domingo de su bando-, ensimismados en el papel de cantores divinos y suplidores del ritual del trisagio de los ángeles ¿Pretendió Berceo caricaturizar a los monjes en su deformación profesional y de rutina - aquella que siempre ejercitaron en el coro terrenal- y exagerar esta actividad de cantores de oficio, como un modo de inadaptación en el cielo?

En la Vida de Santo Domingo de Silos destaca, sobre cualquier otra actuación celestial, la de una continua, múltiple y ejercitada música de alabanza a Dios y, en ocasiones, a sus nuevos huéspedes, con las siguientes variaciones: música monodiada, la del cantus litúrgico mozárabe de la época ("cantaban a Dios laudes"), el discantus (los confesores y vírgenes) y además, si nos atenemos a lo que se dice en el segundo hemistiquio del verso 525d: "Sones multiplicados", interpretando también algún tipo de polifonía a capella, más la instrumental de las vírgenes, "dulcement organando". 
El ceremonial celeste en Del sacrificio de la misa

Se desarrolla en esta obra (coplas 81-82) la idea de un cielo cortesano donde no cesa de sonar, en concierto eterno de ángeles y arcángeles, una música muy del agrado del entendido ReyDios - "voces tales qe plegan al Reï perennal" (81d)—, de cuyos cantos al unísono desea hacernos partícipes Berceo: "qe podamos dar voces con ellos en egual" (c) ${ }^{25}$. Nos preguntamos si, intrusos en el coro angélico, lograremos el mismo nivel de los santos, en el mismo tono, igual canto y de la misma calidad. Pero mientras permanecemos en la "cort terrenal" la misa es una réplica litúrgica del ceremonial de la corte del cielo y los fieles recuerdan a los ángeles cuando entonan el Sanctus, himno cuya autoría adscribe Berceo al profeta

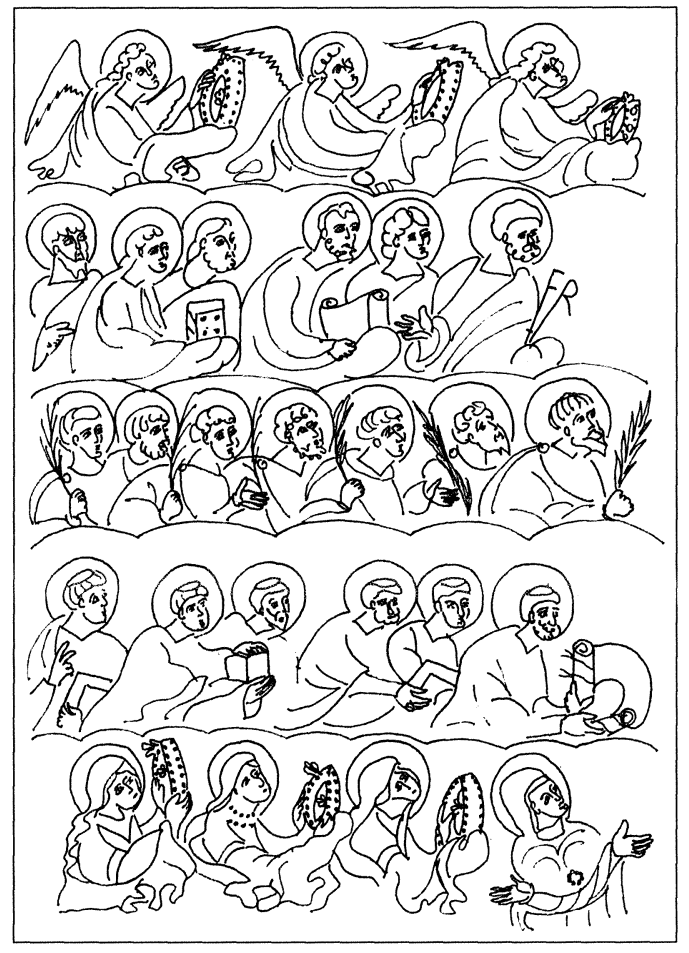

FIGURA 10.-La corte celestial adorando a Cristo. De arriba abajo: ángeles coronadores, apóstoles, mártires portando palmas, confesores y vírgenes con sus coronas, precedidas por María. Fragmento del Sacramentario de Saint Denis, c. 870 (París, Biblioteca Nacional). Dibujo de A. Cea. Isaías:

Desend cantan los Sanctus, signo de alegría, lo qe cantan los ángeles ante Dios cada día; estas laudes avemos del barón Isaía. (82abc)

${ }^{25}$ La última estrofa que cantan las mozas de ramu en la Pereda (Llanes) a N. ${ }^{a}$ S. de Guadalupe en su fiesta, el 2 de agosto, es un traslado fiel de este pasaje berceano: Adiós Madre mía,

hasta que en el cielo

cantemos contigo los siglos eternos.

[¿"siglos" sic por "himnos"?] 
Berceo pudo ver en su tiempo cómo se propagaba el programa iconográfico del triunfo de la Majestad en la Gloria sobre tímpanos y arquivoltas, donde una corte de músicos tañedores —ancianos, apóstoles y ángeles- animaban la figura del pantocrator coronado que la presidía.

Las coronas de los mártires en el Poema de Santa Oria

Solamente en dos pasajes del Poema menciona Berceo a los santos coronados: En el primero (verso 33a), para aludir a las tres vírgenes guionas de Oria (Águeda, Cecilia y Eulalia), perfiladas con ese atributo que, creemos, debe entenderse aquí, más que por su virginidad, conseguido por los martirios que soportaron. Cuando se dice: "Estas tres sanctas vírgenes en Cielo coronadas", no parece haber en esta denominación una expresa intencionalidad de resaltar este sucedido galardón, que se utiliza solo como mero descriptor, topos heredado y dicho cotidiano, que curiosamente ha llegado vivo hasta nuestros días a través del romancero y del cancionero ${ }^{26}$. Sí justifica, en cambio, la corona como mérito del martirio con relación de causa-efecto en el segundo y último pasaje, durante el protocolo de presentación a Oria de esa jerarquía en su primer viaje visionario al cielo:

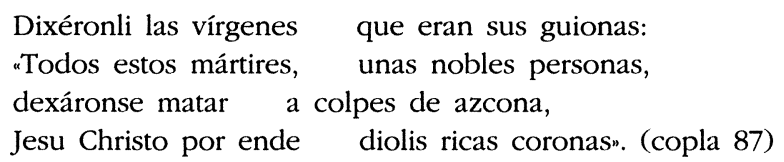

\section{La gran corona del mártir Lorenzo}

Como ya anticipamos, el pensamiento cristiano sostiene como modo más corto y certero de ganar la corona del cielo el camino del martirio, y así lo manifiesta Berceo en El Martirio de San Lorenzo (coplas 72 y 73).

Remedando el pasaje de Getsemaní, se recuerda a Lorenzo la agonía y trance amargo de su Pasión, antes de alcanzar la victoria:

\footnotetext{
${ }^{26}$ Ver en Cea, (1999: nota 8, p. 59). Nuestra informante, Adela Novoa, de 73 años (Miranda del Castañar, 1973), al referirse a su padre, entonces ya fallecido, o a cualquier difunto en general, utilizaba la expresión: "Dios lo tenga coronao de gloria", fórmula mucho más cercana al texto de Berceo que las tan pasivas de: "Dios lo tenga descansando" o "que en paz descanse".
} 


\begin{abstract}
Ante de quinto día, d'esto yo te mesturo, qe te verás en priesa, en torneo muy duro, más tú ternás el campo, d'esto seas seguro, ganarás grand corona mejor de oro puro. Quanto ayas el vaso qe te darán bevido
\end{abstract}

Se presenta el cielo, a renglón seguido, como una corte terrenal donde Lorenzo, en atuendo de rey, sale victorioso de las justas que mantuvo su alma: «luego serás connusco de buen manto vestido, enna corte del Cielo serás bien recebido".

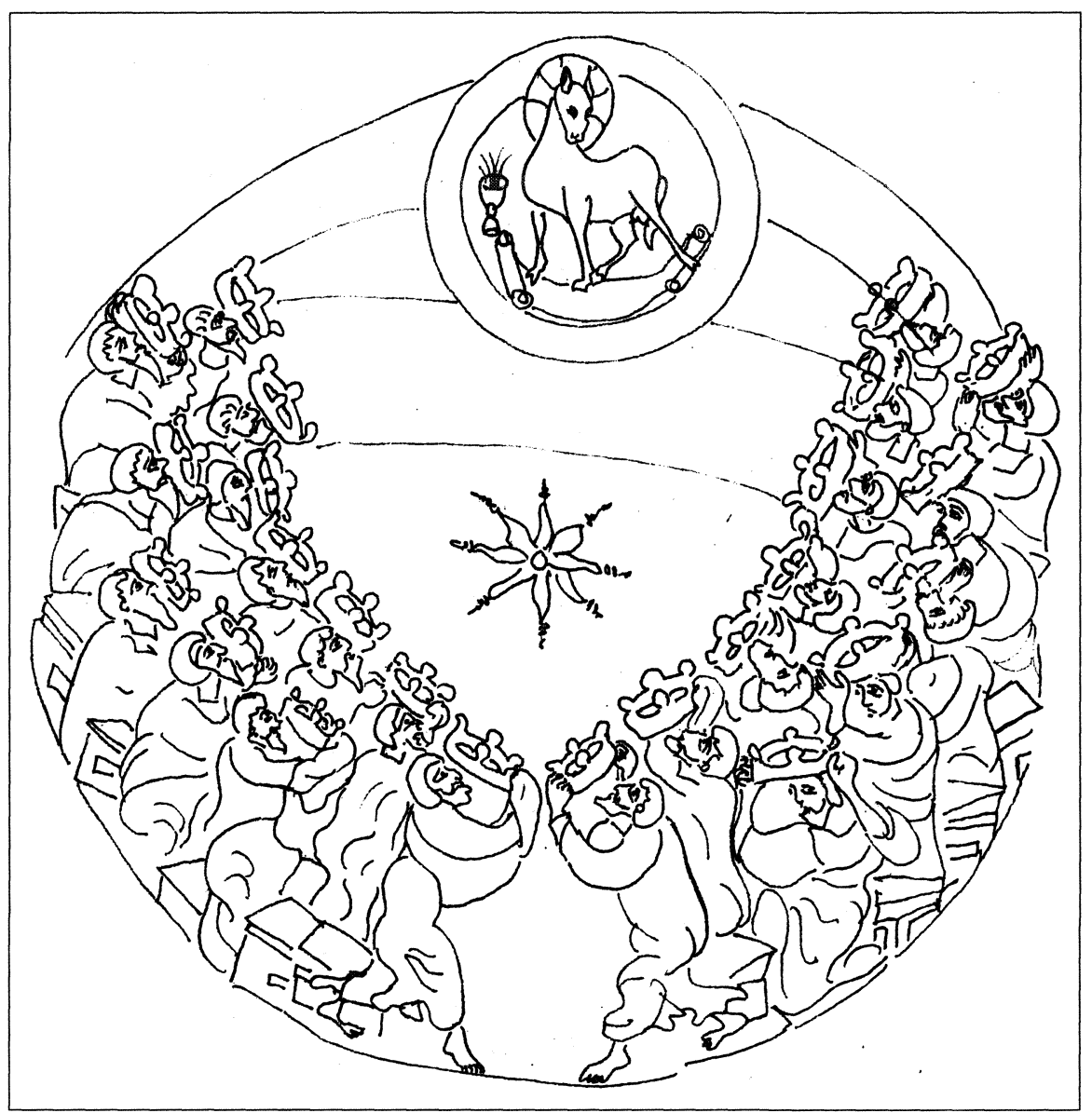

Figura 11.-Los 24 Ancianos, en sus sitiales y coronados, rinden adoración al Cordero místico. Evangelios de San Emerano de Ratisbona, año 870 (Munich, Bayerische Staatsbibliothek). Dibujo de A. Cea. 


\section{Posibles fuentes sagradas para el tema de la corona}

Parece lógico suponer que los galardones celestiales y en concreto la corona, como sucede con otros muchos conceptos de carácter religioso, tengan su fundamento directo en las diferentes fuentes de las Sagradas Escrituras, no solo del Antiguo y el Nuevo Testamento sino de los Evangelios Apócrifos —de los que a menudo se nutren los pasajes literarios e iconográficos de carácter maravilloso-, aunque a veces deriven de modelos culturales distintos al mundo hebraico pero con ascendencia sobre éste; textos de los que, posteriormente, tanto provecho sacó la patrística. En el campo del arte y como préstamo directo y visual debemos señalar para el tema de la coronación como triunfo militar y atlético la influencia directa del mundo clásico romano, que pasa sin estridencias al arte paleocristiano y, sobre todo, la eclosión durante el periodo bizantino de la corona como símbolo que refrenda el poder del rey, que dimana por gracia de la mano directa de Dios. Modelos que gustosamente se mantienen a lo largo del imperio carolingio con sus órbitas de influencia y llegan así hasta las fuentes de las que Berceo bebió.

Desglosamos a continuación estos textos, algunos de cuyos temas desarrolla en su obra el autor emilianense.

La corona como elemento en el ceremonial de coronación de los reyes:

Crónicas 23,11: "Entonces sacaron al hijo del monarca, pusieron sobre él la corona y el testimonio [cetro] y lo proclamaron rey. Yehoyadá y sus hijos lo ungieron y exclamaron: ¡Viva el Rey!n. La primera parte y principal de la unción tenía lugar a puerta cerrada entre el sacerdote, sus acólitos y el monarca. Luego era presentado a los asistentes en el atrio del templo o en una plaza, a las puertas de la ciudad, donde se le imponían los atributos - corona y cetro- y se sentaba en el trono, expresando a continuación, sacerdote y pueblo, la fórmula de aclamación; todo ello en señal de posesión.

Como ejemplo aislado y por imperativo divino, la coronación de un sumo sacerdote, corona que se ofrece luego al templo a manera de elemento votivo:

Zacarias 6, 11 y 14 [Yahveh a Zacarías]: "Tomarás pues la plata y el oro y fabricarás una corona y la pondrás en la cabeza del sumo sacerdote Yehosía [...], y la corona ha de quedar en el templo de Yahveh como recuerdon. No parece que existiera una corona litúrgica exclusivamente destinada a la consagración sacerdotal, más bien es aquí un premio y distinción divinos hacia una persona determinada. Quedaría luego como objeto de admiración para fieles y peregrinos, con otras piezas y donaciones sobresalientes. 


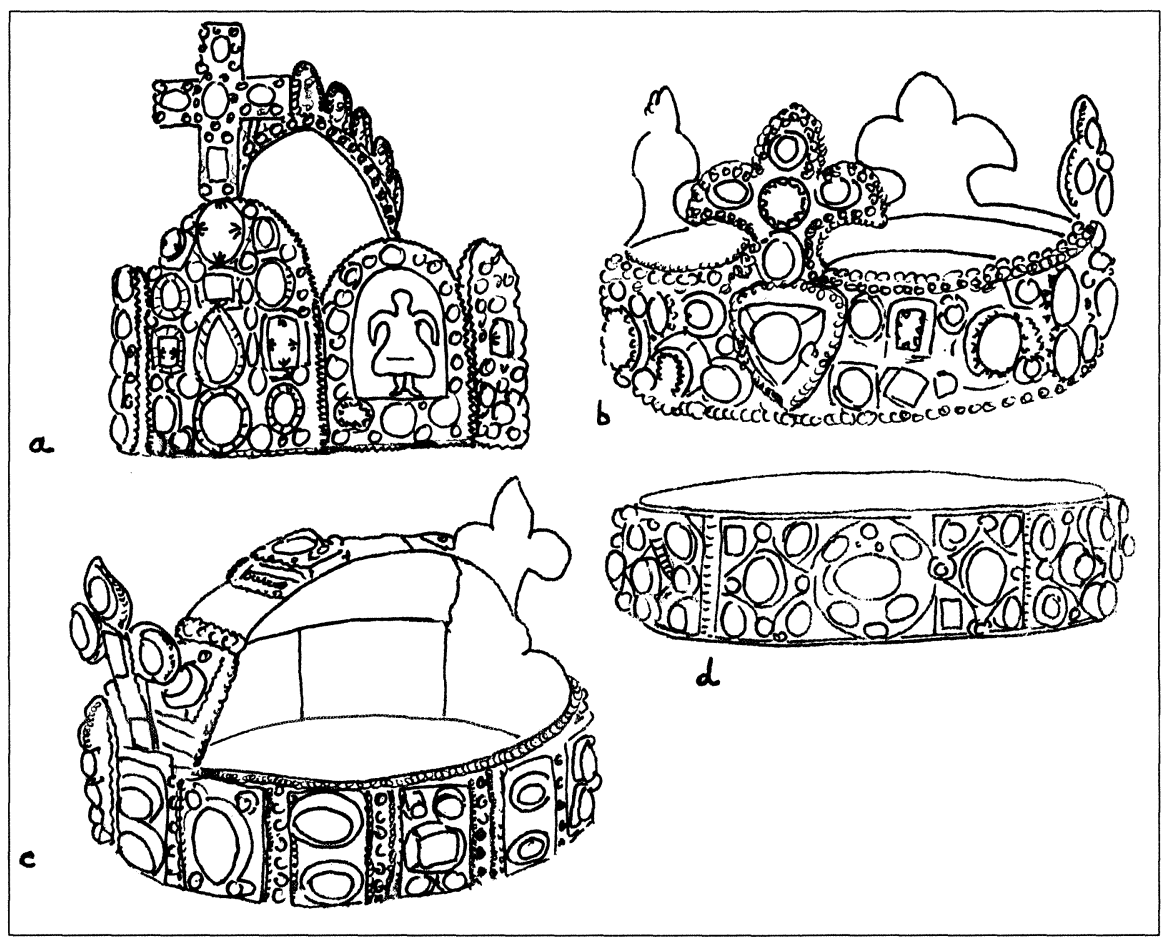

FIGURA 12.-a) Corona del Sacro Imperio, $2 .^{a}$ mitad del $s . x$ con añadidos en el $s$. XI (Viena, Schatzkammer); b) Corona de "la Virgen de Oro", año 983, es la de la coronación de Otón III en Aquisgrán (Essen, tesoro de la catedral); c) Corona de la Majestad de Santa Foy (Conques), finales del siglo x; d) Corona de la emperatriz Cunegunda, $1 .^{\text {er }}$ cuarto del s. XI (Munich, Residenz). Dibujos de A. Cea.

La doble corona como premio a la virtud de Abel:

Pseudo-Mateo VII, 2: "[...] y recibió dos coronas, la de su ofrenda y la de su virginidad. Este pasaje parece tener cercanos paralelos con el de las tres coronas que trae Berceo en la Vida de Santo Domingo de Silos.

La corona como signo de victoria en la lid:

Apocalipsis, 6, 1, 17 y 6,3: "El jinete blanco recibió como vencedor una corona", "...y el que montaba [el caballo blanco] tenía un arco, y le fue dada una corona, y salió vencedor" (se trata en este caso de una corona de laureles para un certante ganador, no corona de rey). “... y vi una nube blanca y sobre ella sentado uno como Hijo del Hombre, que tenía sobre su cabeza corona de oro y en su mano una hoz afilada" $(14,4)$. Se representa así al Dios justiciero como divino segador en la mies madura del Juicio Final. En iconografía la luz como símbolo de la justicia es sustituida, las más de las veces, por la espada que le sale a Cristo de un 
lado de la cabeza o de la boca, elemento que se compensa, de la otra parte, con el lirio de la misericordia.

Para San Pablo sus discípulos son la mejor corona:

Filipenses 4,1: "Así que, hermanos míos queridos y entrañablemente deseados, gozo y corona mía, mantenéos así firmes en el Señor.

La corona de luz personificando a la sabiduría:

Evangelio de Valentino $\mathrm{XX}, 20-24:$ :Y una gran emanación de luz rodeó por todas partes a la Sabiduría [al Hijo:?], a derecha e izquierda, y sobre su cabeza se levantó una corona de luz".

Como atributo de la glorificación de María por su hijo, y de María a los hombres justos:

Evangelio del Tránsito de la Bienaventurada Virgen Maria III, 13: "... porque recibirás de tu hijo corona brillante y la pondrás en las cabezas de los hombres justos". Esta parece ser la interpretación iconográfica a que aludíamos en el Políptico de Gante de Van Eyck: la de la pieza compartida en el ritual de la coronación celestial.

La corona, uno de los elementos, junto con las vestiduras inmortales y los asientos, de la coronación y premio de Cristo a los bienaventurados:

Evangelio cátaro del Pseudo-Juan V, 1-13 y V, 20, 20-23: "Cuando se haya integrado definitivamente el número de los justos que deben ser coronados [...], el ángel hará sonar la trompeta.Y los justos brillarán como el sol en el reino de su Padre [...]. Y el Padre responderá a su hijo [...]: "Hijo mío, siéntate a mi diestra hasta que ponga a tus pies a tus enemigos" [...]. El Hijo se sentará a la diestra de su Padre, y éste mandará en sus ángeles, y él mandará en sus justos. Y les colocará en los coros de los ángeles a fin de vestirlos con inmortales vestidos y les ceñirá coronas que no se marchitarán nunca y les dará asientos inmutables". Se mezclan aquí los dos galardones: corona y silla.

La idea de la participación en el trono y reino del Padre por Cristo y todos los redimidos con su sangre es aprovechada varias veces por San Pablo en sus epístolas:

Hebreos 8,1: “... tenemos un Pontífice [Cristo] tal, que se sentó a la diestra del trono de la Majestad en los cielos".

Timoteo 2, 12 y 4, 18: “...] si constantemente sufrimos, también con él reinaremos". "El Señor me librará de toda obra mala y me salvará, llevándome a su reino celestew. 
Colosenses 3, 24: «[...] Sabiendo que del Señor recibiréis la recompensa de la herencia".

El apóstol San Pedro, en el epílogo de su primera carta a las iglesias del Asia Menor $(5,4)$, sintetiza a la perfección el imperecedero galardón de la corona para los santos, texto que bien puede servir de colofón a este capítulo: ‘[...] cuando apareciere el Pastor, obtendreis la inmarcesible corona de glorian.

Desde un punto de vista experiencial, y dentro de la cultura de nacionalcatolicismo que me tocó vivir cuando niño, pronto me familiaricé con el icono de la corona, comprendiendo su sentido sobre la cabeza de la Virgen y de los santos (además de los importantes elementos que la completaban: el cerco o aureola y el resplandor). Era más enigmática la palma, aprisionada entre los brazos de aquellas imágenes vestidas de romanos, con expresión de arrobo, en hechura de olot, que poblaban las iglesias, o las almibaradas estampas de la calle San Sulpice, en las librerías religiosas del Santander de mi infancia.

Pronto aprendí a asociar la palma al traumatizante tormento martirial -que en este caso era un conocimiento gemelo al de la reciente guerra civil y a la certeza de una muerte para todos, antes del cielo, sin entender el porqué-, cuando en la galería del colegio de la Salle, en Llanes, nos enseñaban como exemplum el cuadro que llamaban "de los Mártires de Turón"; una legión de frailes perdidos con sus palmas entre nubes (ahora canonizados).

Posteriormente, comprendí que la palma, atributo genérico de la virtud heroica en una de las manos de los santos (generalmente la izquierda), ayudaba a una primera clasificación advocacional, que se completaba con la insignia que portaban en la derecha, o la que mostraban sometida a sus pies.

En mi niñez, corona y palma representaban la integración de dos experiencias religiosas complementarias: la sombría de un catolicismo oficial de catequesis y la del cielo doméstico que contaban mis abuelos, donde predominaba la visión de un mundo hedonista, más allá de las nubes, festejante, banquete (dulce) con bailes, cantares y música. 


\section{BIBLIOGRAFÍA CITADA}

BerCeO, G. de. 1971-1981. Obras Completas. Brian Dutton (ed.). London: Tamesis Books. 5 vols.

- 1992. Obras Completas. Brian Dutton (ed.). Madrid: Espasa-Calpe y Gobierno de La Rioja.

La Biblia. 1961. Bover-Cantera, (ed.) Madrid: BAC, 6." ed.

CEA, A. 1992. Religiosidad popular: imágenes vestideras. Zamora: Caja España.

- 1999. "Religiosidad y comunicación interespacial en la Edad Media. Los viajes celestiales en el Poema de Santa Oria", RDTP LIV, 1.': 53-102.

Cirlot, J. E. 1969. Diccionario de símbolos. Barcelona: Labor.

COBARruviaS, S. [1611] 1979, Tesoro de la Lengua Castellana o Española, Madrid: Turner. CORREAS, G. [1627] 1924. Vocabulario de refranes y frases proverbiales. Madrid: Revista de Archivos, Bibliotecas y Museos.

Diccionario de Autoridades. 1963. Madrid: Gredos.

Evangelios Apócrifos. 1934. E. González Blanco (ed.). Madrid: Librería Bergua.

Mena, J. de. 1989. Obras Completas. M. A. Pérez Priego (ed.). Barcelona: Planeta.

Ribadeneyra, P. 1790. Flos Sanctorum... II. Madrid.

TARABON, J. 1973. "Las artes preciosas", El Siglo del Año Mil: 261-349. Madrid: Aguilar. TREnS, M. 1947. María. Iconografía de la Virgen en el Arte Español. Madrid: Plus-Ultra. 